ORIGINAL ARTICLE

\title{
Agricultural pesticide use and adenocarcinomas of the stomach and oesophagus
}

\author{
W J Lee, W Lijinsky, E F Heineman, R S Markin, D D Weisenburger, M H Ward
}

Occup Environ Med 2004;61:743-749. doi: 10.1136/oem.2003.011858

See end of article for authors' affiliations ....................

Correspondence to: Dr M H Ward, 6120 Executive Blvd. EPS 8104, Occupational and Environmental Epidemiology Branch, Division of Cancer Epidemiology and Genetics, National Cancer Institute, Rockville, MD 20852, USA; Wardm@ mail.nih.gov

Accepted 31 March 2004

\begin{abstract}
Aims: To evaluate the risk of the stomach and oesophageal adenocarcinomas associated with farming and agricultural pesticide use.

Methods: Population based case-control study in eastern Nebraska. Telephone interviews were conducted with men and women diagnosed with adenocarcinoma of the stomach $(n=170)$ or oesophagus $(n=137)$ between 1988 and 1993, and controls $(n=502)$ randomly selected from the same geographical area. Unconditional logistic regression was used to calculate adjusted odds ratios (ORs) for farming and for use of individual and chemical classes of insecticides and herbicides, including pesticides classified as nitrosatable (able to form $\mathrm{N}$-nitroso compounds on reaction with nitrite). Non-farmers were used as the reference category for all analyses.

Results: Ever living or working on a farm, duration of farming, and size of the farm were not associated with stomach or oesophageal adenocarcinomas. There was no association for either cancer with ever-use of insecticides (stomach OR $0.9,95 \% \mathrm{Cl} 0.6$ to 1.4 ; oesophagus $\mathrm{OR} 0.7,95 \% \mathrm{Cl} 0.4$ to 1.1 ) or herbicides (stomach OR $0.9,95 \% \mathrm{Cl} 0.5$ to 1.4 ; oesophagus $\mathrm{OR} 0.7,95 \% \mathrm{Cl} 0.4$ to 1.2). Likewise, individual pesticides, including individual nitrosatable pesticides, were not significantly associated with risk.

Conclusions: No significant associations were found between specific agricultural pesticide exposures and the risk of stomach or oesophageal adenocarcinomas among Nebraska farmers.
\end{abstract}

$I^{\mathrm{n}}$ a meta-analysis of 29 studies, farmers had a small but marginally significant increased risk of stomach cancer, although there was considerable heterogeneity across studies. ${ }^{1}$ Excess risks have been seen with different study designs, in different time periods, and in various countries, although negative reports have been published and there is some evidence of confounding due to dietary factors and rural residence. ${ }^{2}$ Exposures to pesticides, organic and inorganic dusts, fertilisers, and diesel fuel have been suggested as contributing to an increased risk of stomach cancer among farmers, although few studies have evaluated specific exposures among farmers. ${ }^{3}$

With few exceptions, ${ }^{45}$ oesophageal cancer risk is lower among farmers compared with the general population or other occupational groups. ${ }^{1}$ However, most studies have not evaluated oesophageal cancer by histological type, and the incidence of adenocarcinomas of the oesophagus and stomach cardia has risen since the mid-1970s in the United States $^{6}$ and other western countries. Obesity, smoking, and gastro-oesophageal reflux account for a large proportion of these cancers, ${ }^{7-9}$ but do not explain all of the increase. A recent case-control study in the United States ${ }^{10}$ evaluated job histories separately for oesophageal squamous cell and adenocarcinomas and found no association for either cancer with employment as a farm worker or for work in agriculture. Specific farming exposures have not been evaluated for oesophageal adenocarcinomas.

Epidemiological studies ${ }^{11}$ provide some support for an association between exposure to pesticides-mostly insecticides of organochlorine origin and phenoxy acid herbicidesand risk of stomach cancer. Increased stomach cancer risk has been observed among many but not all cohorts of herbicide applicators and manufacturers ${ }^{12}$ and insecticide manufacturers. ${ }^{13}$ In a mortality study of aerial pesticide applicators and flight instructors, risks of both stomach and oesophagus cancer was increased. ${ }^{14}$ However, few studies have evaluated cancer risk and specific pesticide exposures.
In the 1970s, it was shown that some pesticide formulations were contaminated with nitrosamines. ${ }^{15}$ The contamination occurred in the manufacturing process or through the reaction of amine containing pesticides with nitrite that was used as a preservative and corrosion inhibitor. ${ }^{16}$ Many pesticides contain amine or amide groups which can react with nitrite and therefore are potential amine precursors for the formation of $\mathrm{N}$-nitroso compounds (NOC) in vivo. ${ }^{17}$ More than 300 pesticide formulations have been surveyed for the presence of nitrosamines or their ability to react with nitrite. ${ }^{18-20}$ Nitrosamine contamination was found in many pesticides commonly used in agriculture; therefore, farmers and other pesticide applicators were likely to have been exposed. Regulations were implemented by the US Environmental Protection Agency in the early 1980s to reduce the likelihood of nitrosamine contamination. ${ }^{21}$

Many NOC are potent animal carcinogens for the stomach, oesophagus, and other organ sites..$^{22-24}$ Specific NOC have been classified by International Agency for Research on Cancer as probably carcinogenic to humans on the basis of sufficient evidence of carcinogenicity in experimental animals and limited evidence of carcinogenicity in humans. ${ }^{25}$ To our knowledge, exposure to nitrosatable pesticides (that is, pesticides able to form $\mathrm{N}$-nitroso compounds on reaction with nitrite) has not been evaluated as a risk factor for stomach or oesophageal cancers in an epidemiological study.

We conducted a population based case control study in Nebraska to determine whether agricultural exposures were associated with the risk of adenocarcinomas of the stomach and oesophagus. An additional aim of our study was to evaluate exposure to NOC and NOC precursors and risk of these cancers. Here we present results for agricultural pesticide use, including use of nitrosatable pesticides.

Abbreviations: $\mathrm{BMI}$, body mass index; $\mathrm{Cl}$, confidence interval; $\mathrm{NOC}$, $\mathrm{N}$-nitroso compounds; OR, odds ratio 
Main messages

- No papers have been published about the hypothesised relation between exposure to nitrosatable pesticides and risk of stomach and oesophageal cancers.

- Results suggest that exposure to agricultural pesticides including nitrosatable pesticides, does not play a role in the development of adenocarcinomas of the stomach and oesophagus.

\section{METHODS}

\section{Study population}

The study population and methods for this population based case-control study have been described in detail. ${ }^{26}$ Briefly, incident cases of stomach and oesophageal cancer cases were identified from the Nebraska Cancer Registry (1988-90) or by review of discharge diagnosis and pathology records at 14 hospitals (1991-93), that accounted for about 90\% of the stomach and oesophageal cancer diagnoses in the eastern 66 counties in Nebraska. Only newly diagnosed cases with confirmed adenocarcinoma of the stomach or oesophagus were retained in the analysis. Eligible cases were white male or female residents of these counties, aged 21 years or older. Cases were limited to whites because the controls were sampled from a previous study that only included whites due to the expected small numbers of other ethnic groups. A series of adult glioma cancer cases was also included in the study.

To reduce the cost of the study, controls were randomly selected from a group of controls interviewed in 1986-87 for a population based case-control study of haematopoietic cancers in Nebraska ${ }^{27}$ in the same 66 counties. Controls under the age of 65 years were selected from the general population by random digit dialling. ${ }^{28}$ Subjects aged 65 years and over were identified from Health Care Financing Administration Medicare files. Controls for deceased cases were selected from Nebraska mortality records with the additional matching factor of year of death. Controls selected for this study were frequency matched by gender and age (five year age groups) to the combined distribution of the stomach, oesophagus, and glioma cases.

\section{Interviews}

Cases and controls or their next-of-kin were interviewed by telephone during 1992-94. Interviews included information about basic demographic characteristics, smoking and alcohol consumption, a family history of cancer, a complete residential and occupational history, and other factors. Dietary information was obtained using a modified version of the Health Habits and History Questionnaire. ${ }^{29}$ Among those who reported living or working on a farm, we asked a detailed history of pesticide use on the farm as well as years of farming activity and the size of the farm where they lived or worked the longest. The pesticide list for the questionnaire was developed with the assistance of local agricultural experts, and included 16 major insecticides and 14 herbicides used on Nebraska crops over the previous 40 years. All of the questions about pesticide use were for the time period before 1985, the time frame of the previous study.

A total of 170 stomach cancer cases, 137 oesophageal cancer cases, and 502 controls completed interviews with overall response rates of $79 \%, 88 \%$, and $83 \%$ respectively. The response rate of controls in the previous study was $87 \%$; therefore, the adjusted rate was $72 \%$ for re-interviewed controls in the current study. Because of the poor prognoses of these cancers, interviews were conducted with a proxy or

\section{Policy implications}

- Further studies are warranted to evaluate risk overall and among potentially high risk subgroups.

the next-of-kin for $76 \%$ of oesophageal adenocarcinoma cases and $80 \%$ of stomach cancer cases. A total of $61 \%$ of control interviews involved proxy respondents. Living controls were over sampled to allow for more study power in subgroup analyses by respondent type. Among controls, spouses (46\%), children $(36 \%)$, and parents $(10 \%)$ were the major proxy respondents. Among stomach and oesophageal cases respectively, spouses $(35 \%, 62 \%)$, children $(46 \%, 28 \%)$, and parents $(7 \%, 11 \%)$ were proxy respondents. Other relatives or friends served as proxies for remaining cases and controls.

\section{Data analysis}

Individual pesticides were grouped into insecticides (aldrin, carbaryl, carbofuran, chlordane, copper acetoarsenite, DDT, diazinon, dieldrin, famphur, fonofos, heptachlor, lindane, malathion, nicotine, phorate, terbufos) and herbicides (2,4,5T, 2,4-D, alachlor, atrazine, chloramben, cyanazine, dicamba, EPTC, glyphosate, metolachlor, metribuzin, pendimethalin, propachlor, trifluralin). We also classified the pesticides into their chemical families: carbamate insecticides (carbaryl, carbofuran), organochlorine insecticides (aldrin, chlordane, DDT, dieldrin, heptachlor, lindane), organophosphorus insecticides (diazinon, famphur, fonofos, malathion, phorate, terbufos), acetanilide herbicides (alachor, metolachlor, propachlor), benzoic acid herbicides (chloramben, dicamba), dinitroaniline herbicides (pendimethalin, trifluralin), phenoxy herbicides (2,4,5-T, 2,4-D), triazine herbicides (atrazine, cyanazine, metribuzin). We estimated the ORs for stomach and oesophageal adenocarcinomas for individual insecticides and herbicides and for the chemical family groupings. Subjects who did not live on a farm after age $18(\mathrm{n}=139)$ were evaluated separately because their reported pesticide use was of short duration and their exposure information was likely to have been poorer than those who farmed as adults.

Additionally, through a review of the literature and the expert judgment of an NOC chemist (W Lijinsky) we grouped the pesticides according to their ability to react with nitrite to form the $\mathrm{N}$-nitroso derivative and the likely carcinogenicity of the nitrosatable derivative as determined from animal studies. For nitrosatable pesticides that had not been tested in animals, a judgement was made (by WL) as to their likely carcinogenicity based on the stability of the $\mathrm{N}$-nitroso derivative and the structural similarity to tested compounds. The nitrosatable pesticide group included pesticides that may have been contaminated with NOC during manufacturing or storage before the mid-1980s. ${ }^{18-20}$

Of the 16 insecticides, four were nitrosatable (carbaryl, carbofuran, famphur, nicotine), whereas 10 of the 14 herbicides were nitrosatable $(2,4,5-\mathrm{T}, 2,4$-D as dialkylamine salts, which are the source of nitrosamine contamination, atrazine, cyanazine, dicamba, EPTC, glyphosate, metolachlor, propachlor, trifluralin). Only five of the nitrosatable derivatives of the herbicides $(2,4,5-\mathrm{T}, 2,4-\mathrm{D}$, EPTC, glyphosate, trifluralin), but all four nitrosatable derivatives of the insecticides had evidence or were judged to be likely to be animal carcinogens. We calculated ORs for the total number of nitrosatable pesticides and for the total years of nitrosatable pesticides use. We used the median values among nitrosatable pesticide users to classify subjects into a low and high category of nitrosatable use. 
We used unconditional logistic regression to calculate odds ratios (ORs) and 95\% confidence intervals (CIs) with Stata software (version 7.0) ${ }^{30}$ All significance tests were two sided $(\alpha=0.05)$. The ORs for farming activity and pesticide use were calculated using non-farmers as a reference group.

All ORs were adjusted for the matching factors of age $(\leqslant 54,55-69, \geqslant 70)$ and gender. We evaluated as possible confounder variables that were significantly associated with risk of each cancer. These included body mass index (BMI), smoking, alcohol consumption, educational level, family history of stomach or oesophageal cancer, respondent type, dietary intake of vitamin A and C, $\beta$-cryptoxanthin, riboflavin, folate, zinc, dietary fibre, protein, and carbohydrate. ${ }^{31}$ Variables were retained in models as confounders when inclusion changed the value of the OR by more than $10 \%$ in any exposure category. Assigning scores to the categorical variables and treating the scored variables as continuous variables in the logistic analyses obtained tests for trend. We also calculated ORs separately by respondent type. We report the results only when the pattern in the ORs differed by respondent type; this occurred for some analyses of the chemical families including the nitrosatable pesticides.

\section{RESULTS}

Table 1 shows the characteristics of the cases and controls. Compared with controls, stomach cancer cases were significantly older, less likely to be alcohol drinkers, and college graduates. Among oesophageal cases there were significantly more men, smokers, and individuals with a higher BMI.

Table 2 shows the adjusted ORs for stomach and oesophageal cancer by farming characteristics. There was no association between ever living or working on a farm and risk of stomach and oesophageal cancers among those who only lived or worked on a farm before age 18 and among adult farmers. We observed no statistically significant ORs by duration of farming and farm size for either cancer among those who farmed as adults.

Table 3 presents ORs for stomach and oesophageal adenocarcinomas and ever-use of pesticides by chemical family among adult farmers. Pesticide use among those who only lived or worked on a farm during childhood was uncommon, which did not allow evaluation of risk among this group. There was no association with ever-use of insecticides and herbicides and stomach cancer risk, whereas ORs were slightly inverse for oesophageal cancer. Benzoic acid herbicide use showed a significant inverse association with stomach cancer $(\mathrm{OR}=0.3 ; 95 \%$ CI 0.1 to 0.8$)$. No other insecticide or herbicide groups were significantly associated with risk of either cancer. The results for oesophageal cancer and some of the chemical families of pesticides were somewhat different among self and proxy respondents. The ORs among self respondents were 1.6 (95\% CI 0.6 to 4.4 ), 1.5 ( $95 \%$ CI 0.5 to 4.7 ), and 2.0 (95\% CI 0.7 to 5.8 ) for use of the organochlorine insecticides, benzoic acid herbicides, and acetanilide herbicides, respectively. Among proxy respondents the associations were inverse: ORs were 0.6 (95\% CI 0.3 to 1.2 ), 0.8 (95\% CI 0.3 to 2.1 ), and 0.6 (95\% CI 0.3 to 1.6 ) for organochlorine insecticides, benzoic acid herbicides, and acetanilide herbicides, respectively.

The ORs for ever-use of specific pesticides are presented in table 4 if there were five or more exposed cases. None of the individual pesticides, including nitrosatable pesticides, were associated with risk of either cancer. Overall, the total number of nitrosatable pesticides and total years of nitrosatable pesticides use were not associated with risk of stomach or oesophageal cancer risk (table 5). We also evaluated exposure as a continuous variable and found no association. However, the patterns in the ORs for oesophageal cancer were somewhat different among self and proxy respondents. The OR for use of four or more nitrosatable pesticides was 1.8 (95\% CI 0.6 to 5.2 ) among self respondents and 0.5 (95\% CI

\begin{tabular}{|c|c|c|c|c|c|c|}
\hline \multirow[b]{2}{*}{ Characteristics } & \multicolumn{2}{|c|}{$\begin{array}{l}\text { Controls } \\
(n=502)\end{array}$} & \multicolumn{2}{|c|}{$\begin{array}{l}\text { Stomach cancer } \\
(n=170)\end{array}$} & \multicolumn{2}{|c|}{$\begin{array}{l}\text { Oesophagus cancer } \\
(n=137)\end{array}$} \\
\hline & No. & $\%$ & Cases & $\%$ & Cases & $\%$ \\
\hline \multicolumn{7}{|l|}{ Age } \\
\hline$\leqslant 54$ & 174 & 34.6 & 22 & 12.9 & 35 & 25.5 \\
\hline $55-69$ & 168 & 33.5 & 58 & 34.1 & 63 & 46.0 \\
\hline$\geqslant 70$ & 160 & 31.9 & 90 & 53.0 & 39 & 28.5 \\
\hline \multicolumn{7}{|l|}{ Gender } \\
\hline Male & 284 & 56.6 & 97 & 57.1 & 121 & 88.3 \\
\hline Female & 218 & 43.4 & 73 & 42.9 & 16 & 11.7 \\
\hline \multicolumn{7}{|l|}{ Smoking } \\
\hline Never & 230 & 48.0 & 87 & 54.7 & 29 & 22.7 \\
\hline$<30$ cigarettes/day & 171 & 35.7 & 47 & 29.6 & 63 & 49.2 \\
\hline$\geqslant 30$ cigarettes/day & 78 & 16.3 & 25 & 15.7 & 36 & 28.1 \\
\hline \multicolumn{7}{|l|}{ Alcohol } \\
\hline Never & 195 & 39.5 & 73 & 43.2 & 30 & 22.2 \\
\hline Current & 162 & 32.8 & 25 & 14.8 & 26 & 19.3 \\
\hline Past & 137 & 27.7 & 71 & 42.0 & 79 & 58.5 \\
\hline \multicolumn{7}{|l|}{ Respondent type } \\
\hline Self & 198 & 39.4 & 34 & 20.0 & 33 & 24.1 \\
\hline Proxy & 304 & 60.6 & 136 & 80.0 & 104 & 75.9 \\
\hline \multicolumn{7}{|l|}{ Education } \\
\hline$<$ College & 294 & 58.6 & 119 & 70.0 & 85 & 62.0 \\
\hline$\geqslant$ College & 208 & 41.4 & 51 & 30.0 & 52 & 38.0 \\
\hline \multicolumn{7}{|c|}{ Body mass index $\left(\mathrm{kg} / \mathrm{m}^{2}\right)$} \\
\hline$\leqslant 23.0$ & 159 & 32.5 & 49 & 29.7 & 24 & 17.8 \\
\hline $23.1-25.0$ & 106 & 21.7 & 25 & 15.2 & 26 & 19.3 \\
\hline $25.1-27.5$ & 115 & 23.5 & 45 & 27.3 & 39 & 28.8 \\
\hline$\geqslant 27.6$ & 109 & 22.3 & 46 & 27.8 & 46 & 34.1 \\
\hline \multicolumn{7}{|c|}{ Family history of gastric or } \\
\hline No & 233 & 508 & 54 & 355 & 60 & 46.5 \\
\hline Yes & 226 & 49.2 & 98 & 64.5 & 69 & 53.5 \\
\hline
\end{tabular}


Table 2 Odds ratios (ORs) and 95\% confidence intervals (Cls) for stomach and oesophageal cancer by farming activity

\begin{tabular}{|c|c|c|c|c|c|c|c|}
\hline & \multirow[b]{2}{*}{ Controls } & \multicolumn{3}{|c|}{ Stomach cancer } & \multicolumn{3}{|c|}{ Oesophageal cancer } \\
\hline & & Cases & $\mathbf{O R}^{*}$ & $95 \% \mathrm{Cl}$ & Cases & $\mathrm{OR}^{*}$ & $95 \% \mathrm{Cl}$ \\
\hline Non-farmers & 184 & 59 & 1.0 & Reft & 62 & 1.0 & Reft \\
\hline \multicolumn{8}{|l|}{ Farmers } \\
\hline Only before age $18 \ddagger$ & 97 & 23 & 0.7 & 0.4 to 1.2 & 19 & 0.6 & 0.3 to 1.1 \\
\hline Adúlt farmers§ & 221 & 88 & 0.9 & 0.6 to 1.3 & 56 & 0.7 & 0.5 to 1.2 \\
\hline \multicolumn{8}{|l|}{ Adult farmers } \\
\hline \multicolumn{8}{|l|}{ Years farmed } \\
\hline$\leqslant 24$ & 73 & 18 & 0.7 & 0.4 to 1.2 & 19 & 0.8 & 0.4 to 1.4 \\
\hline $25-54$ & 70 & 31 & 1.0 & 0.6 to 1.7 & 18 & 0.8 & 0.4 to 1.6 \\
\hline$\geqslant 55$ & 75 & 38 & 1.0 & 0.6 to 1.6 & 19 & 0.7 & 0.4 to 1.3 \\
\hline \multicolumn{8}{|l|}{ Average acres } \\
\hline$<170$ & 79 & 36 & 1.0 & 0.6 to 1.7 & 18 & 0.7 & 0.4 to 1.3 \\
\hline $170-320$ & 63 & 25 & 0.8 & 0.5 to 1.4 & 15 & 0.7 & 0.4 to 1.4 \\
\hline$>320$ & 54 & 18 & 0.8 & 0.4 to 1.6 & 12 & 0.6 & 0.3 to 1.2 \\
\hline
\end{tabular}

0.2 to 1.2 ) among proxies. The results for oesophageal cancer by respondent type for the total years of nitrosatable pesticides use and the subgroup of nitrosatable pesticides that showed evidence of carcinogenicity were similar in that ORs were increased among self respondents and inverse among proxy respondents (data not shown).

\section{DISCUSSION}

We found no evidence of an increased risk of adenocarcinoma of stomach or oesophageal cancer among farmers with the duration of farming and farm size. Furthermore, use of specific chemical families of pesticides and the group of nitrosatable pesticides also showed no association with risk of either cancer. Except for a significant inverse association between benzoic acid herbicides use and stomach cancer, we found no significant association with use of any individual pesticide. The lack of biological plausibility for an inverse association between stomach cancer and benzoic acid herbicides and the small number of cases suggests a noncausal interpretation.

A review of studies of herbicide applicators and producers ${ }^{12}$ found increased risks of stomach cancer in seven cohort studies (one was significantly increased) and no association in three studies. A review of the cohort studies of insecticide manufacturers and applicators found increased stomach cancer mortality; however, excesses were small and were based on a small number of deaths. ${ }^{13}$ Two additional studies found increased risks of stomach cancer. Risk was increased after accounting for a 20 year latency among chlorophenol manufacturers exposed to chlorinated dioxins. ${ }^{32}$ A population based case-control study of stomach cancer in Sweden found an increased risk among those exposed to phenoxy acid herbicides. ${ }^{33}$ In contrast, we found no association between use of phenoxy acid herbicides and either stomach or oesophageal cancer. Most of these studies either did not report oesophageal cancer risk or found an increased association. The hypothesised explanation of decreased oesophageal cancer risk in these studies was the lower prevalence of smoking among farmers in most countries. $^{34}$

Exposure to nitrosatable pesticides or to pesticides contaminated with nitrosamines has been suggested as a possible explanation for the higher rates of stomach cancer among farmers ${ }^{2}$ because of the long standing hypothesis that NOC exposure is a risk factor for this cancer based on animal studies and limited epidemiological evidence. ${ }^{22}{ }^{35}$ Because most $\mathrm{N}$-nitroso compounds are generally systemic carcinogens and not locally acting, it is possible that these contaminants in pesticide formulations contribute to the induction of tumours other than those of the stomach and

Table 3 Odds ratios (ORs) and 95\% confidence intervals (Cls) for stomach and oesophageal cancer for ever-use of pesticides classes among adult farmers

\begin{tabular}{|c|c|c|c|c|c|c|c|}
\hline & \multirow[b]{2}{*}{ Controls } & \multicolumn{3}{|c|}{ Stomach cancer } & \multicolumn{3}{|c|}{ Oesophageal cancer } \\
\hline & & Cases & $\mathrm{OR}^{*}$ & $95 \% \mathrm{Cl}$ & Cases & $\mathrm{OR}^{*}$ & $95 \% \mathrm{Cl}$ \\
\hline Non-farmers & 184 & 59 & 1.0 & Reft & 62 & 1.0 & Reft \\
\hline Insecticides & 129 & 49 & 0.9 & 0.6 to 1.4 & 29 & 0.7 & 0.4 to 1.1 \\
\hline Farmers, no use & 65 & 28 & 0.8 & 0.5 to 1.4 & 17 & 0.8 & 0.4 to 1.6 \\
\hline Carbamate & 61 & 16 & 0.7 & 0.4 to 1.3 & 16 & 0.8 & 0.4 to 1.5 \\
\hline Organochlorine & 83 & 29 & 0.8 & 0.5 to 1.4 & 20 & 0.7 & 0.4 to 1.3 \\
\hline Organophosphorus & 70 & 22 & 0.9 & 0.5 to 1.5 & 16 & 0.6 & 0.3 to 1.2 \\
\hline Herbicides & 111 & 40 & 0.9 & 0.5 to 1.4 & 29 & 0.7 & 0.4 to 1.2 \\
\hline Farmers, no use & 83 & 32 & 0.7 & 0.4 to 1.3 & 17 & 0.6 & 0.3 to 1.2 \\
\hline Acetanilide & 51 & 8 & 0.5 & 0.2 to 1.0 & 16 & 0.8 & 0.4 to 1.6 \\
\hline Benzoic acid & 43 & 4 & 0.3 & 0.1 to 0.8 & 14 & 0.9 & 0.4 to 1.8 \\
\hline Dinitroaniline & 26 & 7 & 0.8 & 0.3 to 2.1 & 6 & 0.7 & 0.3 to 1.8 \\
\hline Phenoxy & 90 & 29 & 0.8 & 0.5 to 1.5 & 20 & 0.7 & 0.4 to 1.2 \\
\hline Triazine & 61 & 19 & 0.8 & 0.5 to 1.5 & 15 & 0.6 & 0.3 to 1.2 \\
\hline
\end{tabular}


Table 4 Odds ratios (ORs) and 95\% confidence intervals (Cls) for stomach and oesophageal cancer by ever-use of individual pesticides among adult farmers

\begin{tabular}{|c|c|c|c|c|c|c|c|}
\hline & \multirow[b]{2}{*}{ Controls } & \multicolumn{3}{|c|}{ Stomach cancer } & \multicolumn{3}{|c|}{ Oesophageal cancer } \\
\hline & & Cases & $\mathrm{OR}^{*}$ & $95 \% \mathrm{Cl}$ & Cases & $\mathrm{OR}^{*}$ & $95 \% \mathrm{Cl}$ \\
\hline Non-farmers & 184 & 59 & 1.0 & Reft & 62 & 1.0 & Reft \\
\hline \multicolumn{8}{|l|}{ Herbicides } \\
\hline $2,4,5-T \ddagger \S$ & 28 & 8 & 0.7 & 0.3 to 1.7 & 7 & 0.7 & 0.3 to 1.9 \\
\hline $2,4-D \ddagger \S$ & 89 & 27 & 0.8 & 0.4 to 1.3 & 20 & 0.7 & 0.4 to 1.2 \\
\hline Alachlor & 40 & 7 & 0.5 & 0.2 to 1.3 & 12 & 0.8 & 0.4 to 1.7 \\
\hline Atrazine $\neq$ & 55 & 18 & 0.9 & 0.5 to 1.6 & 15 & 0.7 & 0.4 to 1.4 \\
\hline Cyananzineł & 20 & 1 & 0.2 & 0.1 to 1.3 & 5 & 0.8 & 0.3 to 2.4 \\
\hline Dicambał & 35 & 4 & 0.3 & 0.1 to 1.0 & 13 & 0.9 & 0.5 to 1.9 \\
\hline EPTC $§ \S$ & 28 & 6 & 0.6 & 0.2 to 1.5 & 9 & 0.8 & 0.3 to 1.8 \\
\hline Glyphosate $\S$ & 46 & 12 & 0.8 & 0.4 to 1.5 & 12 & 0.7 & 0.3 to 1.4 \\
\hline Propachlorf & 27 & 5 & 0.5 & 0.2 to 1.4 & 10 & 0.9 & 0.4 to 2.1 \\
\hline Trifluralin $\ddagger \S$ & 24 & 6 & 0.8 & 0.3 to 2.1 & 5 & 0.7 & 0.2 to 1.9 \\
\hline \multicolumn{8}{|l|}{ Insecticides } \\
\hline Aldrin & 30 & 6 & 0.4 & 0.2 to 1.1 & 8 & 0.8 & 0.3 to 1.8 \\
\hline Carbaryl¥£ & 47 & 9 & 0.5 & 0.2 to 1.2 & 12 & 0.7 & 0.4 to 1.5 \\
\hline Carbofuran $\ddagger \S$ & 36 & 9 & 0.7 & 0.3 to 1.6 & 11 & 0.8 & 0.4 to 1.8 \\
\hline Chlordane & 40 & 15 & 0.9 & 0.5 to 1.8 & 10 & 0.6 & 0.3 to 1.4 \\
\hline DDT & 65 & 27 & 0.9 & 0.5 to 1.6 & 16 & 0.8 & 0.4 to 1.5 \\
\hline Diazinon & 35 & 6 & 0.5 & 0.2 to 1.2 & 10 & 0.8 & 0.4 to 1.8 \\
\hline Dieldrin & 23 & 6 & 0.6 & 0.2 to 1.5 & 5 & 0.5 & 0.2 to 1.5 \\
\hline Fonofos & 26 & 5 & 0.5 & 0.2 to 1.4 & 7 & 0.8 & 0.3 to 1.9 \\
\hline Lindane & 36 & 8 & 0.5 & 0.2 to 1.2 & 8 & 0.6 & 0.3 to 1.5 \\
\hline Malathion & 46 & 14 & 0.8 & 0.4 to 1.6 & 12 & 0.7 & 0.4 to 1.5 \\
\hline Nicotineł§ & 23 & 10 & 0.9 & 0.4 to 2.0 & 4 & 0.5 & 0.2 to 1.5 \\
\hline Phorate & 26 & 6 & 0.6 & 0.2 to 1.7 & 10 & 1.1 & 0.5 to 2.6 \\
\hline Terbufos & 29 & 5 & 0.6 & 0.2 to 1.6 & 6 & 0.6 & 0.2 to 1.5 \\
\hline
\end{tabular}

oesophagus. A positive association between occupational nitrosamine exposure and having detectable $\mathrm{O}^{6}$-methylguanine adducts in peripheral blood has been found in rubber industry workers. ${ }^{36}$ Because these DNA adducts have mutagenic potential and may play a role in carcinogenesis, ${ }^{37}$ this finding supports the biological plausibility of an

Table 5 Odds ratios (ORs) and $95 \%$ confidence intervals (Cls) for stomach and oesophageal cancer by number of nitrosatable pesticides used and years of nitrosatable pesticides used among adult farmers

\begin{tabular}{|c|c|c|c|c|c|}
\hline & Cases & Controls & $\mathrm{OR}^{*}$ & $95 \% \mathrm{Cl}$ & $\begin{array}{l}p \text { value for } \\
\text { trend }\end{array}$ \\
\hline \multirow{2}{*}{\multicolumn{6}{|c|}{ Total number of nitrosatable pesticides usdeł }} \\
\hline Stomach & & & & & \\
\hline Non-farmers & 59 & 184 & 1.0 & Reft & \\
\hline 0 & 52 & 122 & 0.9 & 0.5 to 1.4 & \\
\hline $1-3$ & 21 & 38 & 1.2 & 0.6 to 2.2 & \\
\hline$\geqslant 4$ & 15 & 61 & 0.7 & 0.3 to 1.3 & 0.436 \\
\hline \multicolumn{6}{|l|}{ Oesophagus } \\
\hline Non-farmers & 62 & 184 & 1.0 & Reft & \\
\hline 0 & 33 & 122 & 0.8 & 0.5 to 1.4 & \\
\hline $1-3$ & 6 & 38 & 0.5 & 0.2 to 1.2 & \\
\hline$\geqslant 4$ & 17 & 61 & 0.7 & 0.4 to 1.4 & 0.206 \\
\hline \multicolumn{6}{|c|}{ Total year of nitrosatable pesticides used§ } \\
\hline \multicolumn{6}{|l|}{ Stomach } \\
\hline Non-farmers & 59 & 184 & 1.0 & Reft & \\
\hline 0 & 70 & 159 & 0.9 & 0.6 to 1.4 & \\
\hline$\leqslant 20$ & 9 & 35 & 0.7 & 0.3 to 1.7 & \\
\hline$>20$ & 9 & 27 & 0.8 & 0.3 to 1.8 & 0.414 \\
\hline \multicolumn{6}{|l|}{ Oesophagus } \\
\hline Non-farmers & 62 & 184 & 1.0 & Reft & \\
\hline 0 & 42 & 159 & 0.8 & 0.5 to 1.3 & \\
\hline$\leqslant 20$ & 5 & 35 & 0.4 & 0.2 to 1.1 & \\
\hline$>20$ & 9 & 27 & 0.8 & 0.4 to 1.9 & 0.203 \\
\hline \multicolumn{6}{|c|}{$\begin{array}{l}\text { *Odds ratio adjusted for age and gender. } \\
\text { †Reference category: non-farmers. } \\
\text { †Sum of total number of nitrosatable pesticides used. } \\
\text { §From first to last year of nitrosatable pesticides used. }\end{array}$} \\
\hline
\end{tabular}


association between NOC exposure and human cancer development.

Humans are exposed to preformed $\mathrm{N}$-nitroso compounds from a variety of sources. ${ }^{38}{ }^{39}$ Dietary intakes are estimated to contribute the majority of NOC exposure ${ }^{39}$ However, nitrate exposure in drinking water can be a significant contributor to total nitrate intake and to potential NOC exposure when levels are at or above the maximum contaminant level of $10 \mathrm{mg} / \mathrm{l}^{40}{ }^{41}$ In this study population, dietary sources of NOC were not significantly associated with risk of stomach and oesophagus cancer, ${ }^{31}$ nor were nitrate levels in public water supplies ( $\mathrm{M}$ Ward, unpublished data). It is also important to consider that the routes of exposure are different for nitrosatable pesticides (inhalation and dermal) versus dietary NOC or NOC precursors (ingestion). Relative to other sources of NOC exposure, occupational exposure via agricultural pesticide use may be small and for this reason it may not be significant for the development of stomach or oesophageal cancer. However, that does not rule out the possibility of an increased risk among those with higher exposures or among subgroups with increased ability to metabolise nitrosamines. ${ }^{42-44}$

The limitations of this analysis were the possible misclassification of pesticide exposure and the generally small number of farmers exposed to some of the individual pesticides. Although the assessment of nitrosability of each pesticide was based on chemical structure and a detailed literature review, misclassification of exposure may have occurred because the nitrosamine contamination of the pesticide formulation was likely to be variable, and we also lacked information on the ease of nitrosation for some pesticides. This potential misclassification would be expected to be non-differential for cases and controls and the observed effect estimates would likely be biased towards the null. Misclassification of exposure is also possible because data related to past exposure to pesticides were obtained by interviews with study subjects or their proxy respondents. In our study, proxies were more likely to provide "don't know" responses and were less likely to report use of specific pesticides than subjects themselves, as has been reported by others. ${ }^{45}{ }^{46}$ However, in spite of some evidence of underreporting of exposure by proxies, the different pattern by respondent type was limited to oesophageal cancer.

In summary, we found no significant associations between agricultural pesticide exposures and the risk of adenocarcinoma of stomach or oesophagus among Nebraska farmers. However, further evaluation of this hypothesis in larger studies with genetic information on nitrosamine metabolising enzymes is warranted to evaluate risk among potentially high risk subgroups of pesticide applicators.

\section{Authors' affiliations}

W J Lee, M H Ward, Occupational and Environmental Epidemiology Branch, Division of Cancer Epidemiology and Genetics, National

Cancer Institute, Bethesda, MD, USA

E F Heineman, Division of Cancer Epidemiology and Genetics, National Cancer Institute, Bethesda, MD, USA

R S Markin, D D Weisenburger, University of Nebraska Medical Center, Omaha, NE, USA

Note: Dr William Lijinsky is deceased

\section{REFERENCES}

1 Acquavella J, Olsen G, Cole P, et al. Cancer among farmers: a meta-analysis. Ann Epidemiol 1998:8:64-74.

2 Cocco $P$, Ward MH, Buiatti E. Occupational risk factors for gastric cancer: an overview. Epidemiol Rev 1996;18:218-34.

3 Blair A, Zahm SH. Cancer among farmers. Occup Med 1991;6:335-54.

4 Ronco G, Costa G, Lynge E. Cancer risk among Danish and Italian farmers. $\mathrm{Br} J$ Ind Med 1992;49:220-5.
5 Cherie-Challine L, Pottier D, Gignoux M. [Descriptive epidemiology of cancer of the esophagus in the Department of Calvados: 520 cases (1978-1982)]. Gastroenterol Clin Biol 1988;12:126-32.

6 Devesa SS, Blot WJ, Fraumeni JF Jr. Changing patterns in the incidence of esophageal and gastric carcinoma in the United States. Cancer 1998;83:2049-53.

7 Gammon MD, Schoenberg JB, Ahsan H, et al. Tobacco, alcohol, and socioeconomic status and adenocarcinomas of the esophagus and gastric cardia. J Natl Cancer Inst 1997:89:1277-84.

8 Chow WH, Blot WJ, Vaughan TL, et al. Body mass index and risk of adenocarcinomas of the esophagus and gastric cardia. J Natl Cancer Inst 1998:90:150-5.

9 Farrow DC, Vaughan TL, Sweeney C, et al. Gastroesophageal reflux disease, use of $\mathrm{H} 2$ receptor antagonists, and risk of esophageal and gastric cancer. Cancer Causes Control 2000;11:231-8.

10 Engel LS, Vaughan TL, Gammon MD, et al. Occupation and risk of esophageal and gastric cardia adenocarcinoma. Am J Ind Med 2002;42:11-22.

11 Dich J, Zahm SH, Hanberg A, et al. Pesticides and cancer. Cancer Causes Control 1997;8:420-43.

12 Morrison HI, Wilkins K, Semenciw R, et al. Herbicides and cancer. J Natl Cancer Inst 1992;84:1866-74.

13 Blair A, Axeloson O, Franklin C. Carcinogenic effects of pesticides. In: Baker SR, Wilkinson CF, eds. The effects of pesticides on human health Advances in modern environmental toxicology. Princeton: Scientific Publishing Company, 1990:201-60.

14 Cantor KP, Silberman W. Mortality among aerial pesticide applicators and flight instructors: follow-up from 1965-1988. Am J Ind Med 1999:36:239-47.

15 Ross RD, Morrison J, Rounbehler DP, et al. N-nitroso-compound impurities in herbicide formulations. J Agric Food Chem 1977;25:1416-18.

16 Probst GW. Reduction of nitrosamine impurities in pesticide formations. In: Scanlan RA, Tannenbaum SR, eds. N-nitro compounds. Washington, DC: American Chemical Society, 1981:363-81.

17 Preussmann R, Eisenbrand G. N-nitroso carcinogens in the environment. In: Searle CE, ed. Chemical carcinogens. Washington, DC: American Chemical Society, 1984:829-68.

18 Cohen SZ, Zweig G. Analytical determination of N-nitroso compounds in pesticides by the United States Environmental Protection Agency-a preliminary study. IARC Sci Publ 1978:333-42.

19 Bontoyan WR, Law MW, Wright DP Jr. Nitrosamines in agricultural and home-use pesticides. J Agric Food Chem 1979:27:631-35.

20 Zweig G, Selim S, Hummel R, et al. Analytical survey of N-nitroso contaminants in pesticide products. IARC Sci Publ 1980:555-64.

21 Zweig G, Garner W. Policy and regulatory aspects of N-nitroso contaminants in pesticide products. In: Scanlan RA, Tannenbaum SR, eds. N-nitroso compounds. Washington, DC: American Chemical Society, 1981:383-9

22 Mirvish SS. Role of $\mathrm{N}$-nitroso compounds (NOC) and $\mathrm{N}$-nitrosation in etiology of gastric, esophageal, nasopharyngeal and bladder cancer and contribution to cancer of known exposures to NOC. Cancer Lett 1995;93:17-48.

23 Magee PN. The experimental basis for the role of nitroso compounds in human cancer. Cancer Surv 1989;8:207-39.

24 Preston-Martin S, Correa P. Epidemiological evidence for the role of nitroso compounds in human cancer. Cancer Surv 1989:8:459-73.

25 IARC. Monographs on the evaluation of the carcinogenic risk of chemicals to humans: some N-nitroso compounds. IARC Monogr Eval Carcinog Risk Chem Man 1978;17:1-349.

26 Ward MH, Sinha R, Heineman EF, et al. Risk of adenocarcinoma of the stomach and esophagus with meat cooking method and doneness preference. Int J Cancer 1997;71:14-19.

27 Zahm SH, Weisenburger DD, Babbitt PA, et al. A case-control study of nonHodgkin's lymphoma and the herbicide 2,4-dichlorophenoxyacetic acid (2,4D) in eastern Nebraska. Epidemiology 1990;1:349-56.

28 Hartge $\mathbf{P}$, Brinton LA, Rosenthal JF, et al. Random digit dialing in selecting a population-based control group. Am J Epidemiol 1984;120:825-33.

29 Block G, Hartman AM, Naughton D. A reduced dietary questionnaire development and validation. Epidemiology 1990;1:58-64.

30 StataCorp. Stata Reference Manual, release 7. Texas: Stata Press, 2001

31 Chen $\mathrm{H}$, Ward MH, Graubard BI, et al. Dietary patterns and adenocarcinoma of the esophagus and distal stomach. Am J Clin Nutr 2002;75:137-44.

32 Ott MG, Olson RA, Cook RR, et al. Cohort mortality study of chemical workers with potential exposure to the higher chlorinated dioxins. J Occup Med 1987;29:422-9.

33 Ekstrom AM, Eriksson M, Hansson LE, et al. Occupational exposures and risk of gastric cancer in a population-based case-control study. Cancer Res 1999:59:5932-7.

34 Blair A, Zahm SH, Pearce NE, et al. Clues to cancer etiology from studies of farmers. Scand I Work Environ Health 1992;18:209-15.

35 Correa P. Human gastric carcinogenesis: a multistep and multifactorial process - first American Cancer Society Award Lecture on Cancer Epidemiology and Prevention. Cancer Res 1992;52:6735-40.

36 Reh BD, DeBord DG, Butler MA, et al. O(6)-methylguanine DNA adducts associated with occupational nitrosamine exposure. Carcinogenesis 2000:21:29-33

37 Saffhill R, Margison GP, O'Connor PJ. Mechanisms of carcinogenesis induced by alkylating agents. Biochim Biophys Acta 1985;823:111-45.

38 Lijinsky W. Reaction of drugs with nitrous acid as a source of carcinogenic nitrosamines. Cancer Res 1974:34:255-8.

39 Tricker AR. N-nitroso compounds and man: sources of exposure, endogenous formation and occurrence in body fluids. Eur J Cancer Prev 1997;6:226-68. 
40 National Academy of Sciences. The health effects of nitrate, nitrite and N-nitroso compounds. Washington, DC: National Academy Press 1981.

41 Mirvish SS, Grandjean AC, Moller H, et al. N-nitrosoproline excretion by rural Nebraskans drinking water of varied nitrate content. Cancer Epidemiol Biomarkers Prev 1992;1:455-61.

42 Yang CS, Yoo JS, Ishizaki H, et al. Cytochrome P450IIE1: roles in nitrosamine metabolism and mechanisms of regulation. Drug Metab Rev 1990;22:147-59.

43 Kushida H, Fujita K, Suzuki A, et al. Metabolic activation of Nalkylnitrosamines in genetically engineered Salmonella typhimurium expressing CYP2E1 or CYP2A6 together with human NADPH-cytochrome P450 reductase. Carcinogenesis 2000;21:1227-32.

44 Godoy W, Albano RM, Moraes EG, et al. CYP2A6/2A7 and CYP2E1 expression in human oesophageal mucosa: regional and inter-individua variation in expression and relevance to nitrosamine metabolism. Carcinogenesis 2002;23:611-16.

45 Blair A, Zahm SH. Patterns of pesticide use among farmers: implications for epidemiologic research. Epidemiology 1993:4:55-62.

46 Blair A, Kross B, Stewart PA, et al. Comparability of information on pesticides use obtained from farmers and their proxy respondents. J Agric Saf Health 1995;1:165-76.

\section{Clinical Evidence - Call for contributors}

Clinical Evidence is a regularly updated evidence based journal available worldwide both as a paper version and on the internet. Clinical Evidence needs to recruit a number of new contributors. Contributors are health care professionals or epidemiologists with experience in evidence based medicine and the ability to write in a concise and structured way.

\section{Currently, we are interested in finding contributors with an interest in} the following clinical areas:

Altitude sickness; Autism; Basal cell carcinoma; Breast feeding; Carbon monoxide poisoning; Cervical cancer; Cystic fibrosis; Ectopic pregnancy; Grief/bereavement; Halitosis; Hodgkins disease; Infectious mononucleosis (glandular fever); Kidney stones; Malignant melanoma (metastatic); Mesothelioma; Myeloma; Ovarian cyst; Pancreatitis (acute); Pancreatitis (chronic); Polymyalgia rheumatica; Post-partum haemorrhage; Pulmonary embolism; Recurrent miscarriage; Repetitive strain injury; Scoliosis; Seasonal affective disorder; Squint; Systemic lupus erythematosus; Testicular cancer; Varicocele; Viral meningitis; Vitiligo However, we are always looking for others, so do not let this list discourage you.

Being a contributor involves:

- Appraising the results of literature searches (performed by our Information Specialists) to identify high quality evidence for inclusion in the journal.

- Writing to a highly structured template (about 2000-3000 words), using evidence from selected studies, within 6-8 weeks of receiving the literature search results.

- Working with Clinical Evidence Editors to ensure that the text meets rigorous epidemiological and style standards.

- Updating the text every eight months to incorporate new evidence.

- Expanding the topic to include new questions once every 12-18 months.

If you would like to become a contributor for Clinical Evidence or require more information about what this involves please send your contact details and a copy of your CV, clearly stating the clinical area you are interested in, to Claire Folkes (cfolkes@bmigroup.com).

\section{Call for peer reviewers}

Clinical Evidence also needs to recruit a number of new peer reviewers specifically with an interest in the clinical areas stated above, and also others related to general practice. Peer reviewers are health care professionals or epidemiologists with experience in evidence based medicine. As a peer reviewer you would be asked for your views on the clinical relevance, validity, and accessibility of specific topics within the journal, and their usefulness to the intended audience (international generalists and health care professionals, possibly with limited statistical knowledge). Topics are usually 2000-3000 words in length and we would ask you to review between 2-5 topics per year. The peer review process takes place throughout the year, and our turnaround time for each review is ideally 10-14 days.

If you are interested in becoming a peer reviewer for Clinical Evidence, please complete the peer review questionnaire at www.clinicalevidence.com or contact Claire Folkes(cfolkes@bmigroup.com). 